V. Smoliar, I. Sliusar, I. Chernytska, V. Knysh, O. Orysenko

Poltava National Technical Yuri Kondratyuk University, Poltava, Ukraine

\title{
INCREASING THE PRODUCTIVITY OF THE BRIDGE CRANE DUE TO THE INTRODUCTION OF ARDUINO'S HARDWARE AND SOFTWARE BASE IN ITS CONTROL SYSTEM
}

\begin{abstract}
The research results of the possibility of increasing the productivity of the bridge crane through the introduction of hardware and software base Arduino in its control system are given in the article. The indexes of technical productivity of batch operation lift and carry machines of periodic action are analyzed and the working cycle duration has been shortened. Several cases (successive execution -- each subsequent movement only begins after the end of the previous one; partial combination - combine only a few separate movements are combined; full alignment - all crane movements with the load are combined in time) is considered. In this article, based on the results of the analysis, the control of the load-lifting machine was built due to of the introduction of telecommunication systems and technologies, namely the use of microcontrollers with the implementation of control using wired (Ethernet) or wireless (Bluetooth, Wi-Fi) network. Because there is the need to increase the productivity of lift and carry machines, to improve the working conditions of personnel, to improve the reliability and durability of machine elements, causes the creation of new, more advanced systems of machine management and partial or complete automation of their work. Safety in the production will increase significantly with this technology, as it will be possible to implement protection against overload, excess speed, rocking, moving cargo to areas where people are located and so on the results of the article are shown. Crane management can be done either from the operator's cab, directly controlled by the controller, or remotely, by transmitting signals over wired (Ethernet) or wireless (Bluetooth, Wi-Fi) networks.
\end{abstract}

Keywords: bridge crane, automation, controller, technical performance, combination of working operations, Arduino, Ethernet, Bluetooth, Wi-Fi, lift and carry machine, load-lifting machine.

\section{Introduction}

Problem statement. The need to increase the productivity of lift and carry machines, to improve the working conditions of personnel, to improve the reliability and durability of machine elements, causes the creation of new, more advanced systems of machine management and partial or complete automation of their work.

Even partial automation of some processes of the load-lifting machines leads to a significant increase in its productivity.

Thus, for example, automatic smooth reduction of speed before stopping and ensuring accurate landing of cargo allow to increase the speed of goods and empty crane hook movement, which leads to a decrease in the required number of lift and carry machines, to reducing the number of servicemen, improving the working hours of the machine and to improving working conditions of employees [1].

The automation of the load-lifting machine also has a significant effect in such cases, for example, when performing assembly work with large-sized products, as well as during unloading of holds of vessels, when it is impossible to see the position of a crane hook and load from the cockpit, and the connection between the crane operator and the worker, who is in close proximity to the cargo is complicated. The use of portable remote control increases the accuracy of assembly and reloading operations, as maintenance staff can be located in close proximity to the transported object.

Remote control is also necessary in cases when, under conditions of performance, maintenance staff must be located at a distance from the moving cargo.
Achievement of the indicated results at a high level is possible only at the expense of introduction of telecommunication systems and technologies in the means of controlling the load-lifting machine.

Analysis of research and publications on this problem. Systems of electronic control and control of load-lifting equipment are widely used in different countries of the world and are relevant for implementation in various spheres of activity.

Examples of the application of such technologies are presented in [4-8].

The purpose of this article is to highlight the results of the study of the possibility of increasing the productivity of the bridge crane due to the use of in microcontrollers its means of control.

\section{The main content}

The technical performance of batch operation of lift and carry machines, which include bay cranes, is expressed in $\mathrm{t} / \mathrm{h}$ and is calculated by equation:

$$
Q=q \cdot a \cdot n,
$$

where $\mathrm{q}$ is load-carrying capacity of the machine;

$\mathrm{a}$ is a coefficient of the car use per loadcarrying capacity;

$\mathrm{n}$ is a number of cycles that a car performs in one hour of work.

The number of cycles $\mathrm{n}$ is calculated as:

$$
n=\frac{3600}{t_{s}}
$$

where $t_{s}$ is the duration of one cycle in seconds.

After analyzing these mathematical dependencies, it was concluded that by reducing the duration of one 
cycle, an increase in machine productivity can be achieved.

The duration of a cycle depends on a number of factors and is determined by the formula:

$$
t_{s}=t_{w}+t_{a},
$$

where $t_{w}$ is the time spent by the crane on moving the cargo along on the spatial trajectory;

$t_{a}$ is time spent on auxiliary operations, for example, seizure of goods.

If you do not take into account the possibility of automatic capture of cargo, then its possible to shorten the duration of the working cycle by reducing the time to perform crane work movements. Several cases are possible:

- successive execution - each subsequent movement only begins after the end of the previous one;

- partial combination - combine only a few separate movements are combined;

- full alignment - all crane movements with the load are combined in time.

Thus, for a bridge crane with a consistent performance of working motions, the duration of a cycle is calculated according to the following formula [2]:

$$
t_{s}=\frac{4 \cdot H}{V_{0}}+2\left(\frac{l_{1}}{V_{1}}+\frac{l_{2}}{V_{2}}\right)+t_{a},
$$

where $\mathrm{H}, \mathrm{l}_{1}, \mathrm{l}_{2}$ are respectively, the average values of the load lifting height, the distance of the crane and the cart movement;

$\mathrm{V}_{0}, \mathrm{~V}_{1}, \mathrm{~V}_{2}$, are respectively, the speed of lifting the load, the movement of the crane and of freight truck;

$t_{a}$ is the time spent on auxiliary operations.

For stacker cranes with automatic control the cycle time is calculated taking into account the alignment of movement along the rack with vertical movement [2]:

$$
t_{s}=2\left(\frac{l_{1}}{V_{1}}+\frac{l_{2}}{V_{2}}\right)+t_{a}
$$

Comparing the given formulas, a significant time saving in the case of automatic control and combination of work movements (in the formula for calculating the duration of the working cycle for the stacker crane there is no component $4 \cdot H / V_{0}$, which determines the time of vertically cargo movement) can be notice (fig. 1).
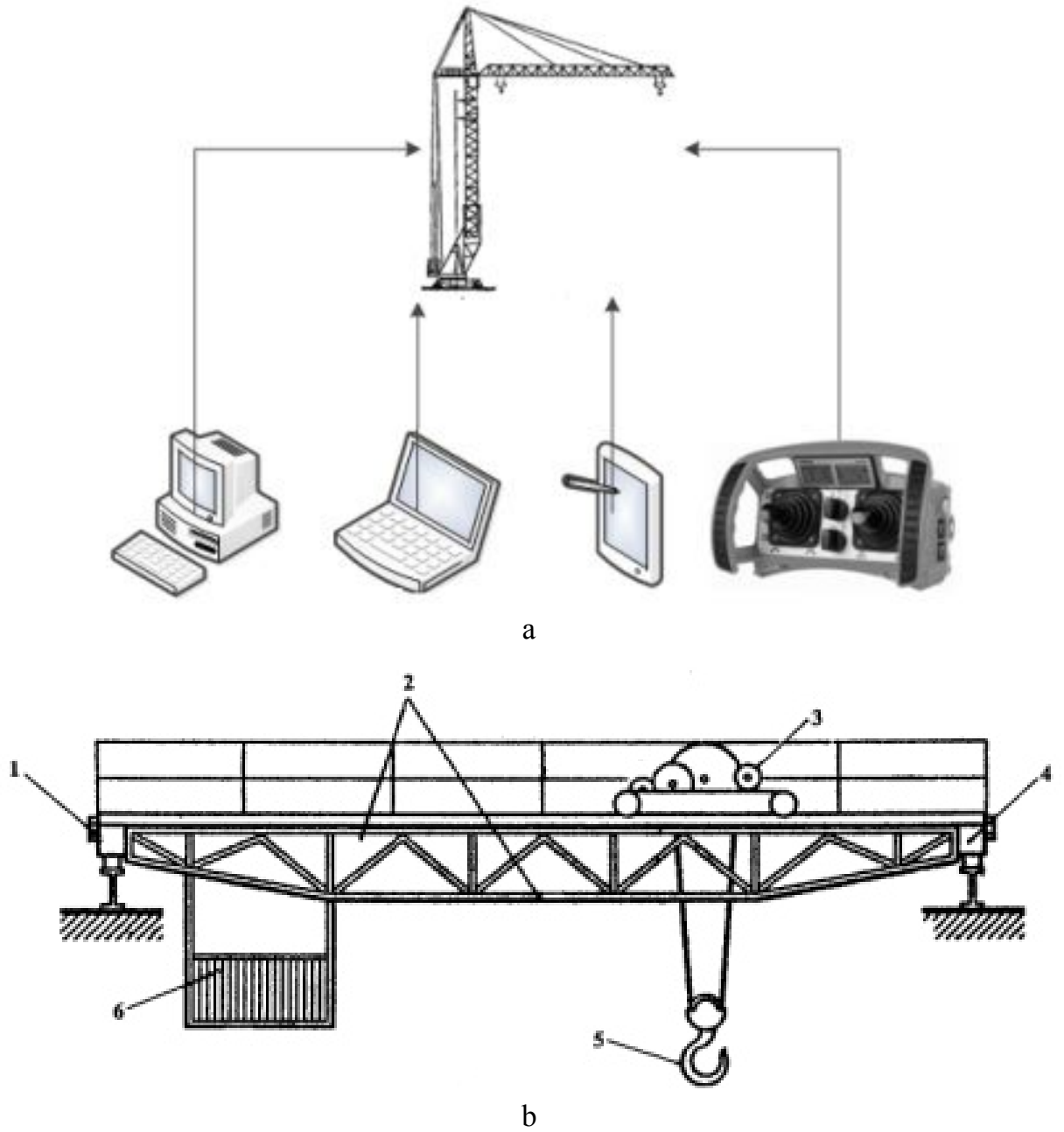

Fig. 1. Options for managing the crane with different devices

However, it is not possible to achieve the optimal combination of worker movements only at the expense of the operator's qualifications. This is due to his abilities. So, according to [3], if a crane operator is highly 
qualified, it is possible to combine only two and in some cases (with small work intensity) three working movements.

Thus, the maximum possible reduction in the duration of the working cycle, which can be achieved under these conditions, is $20-30 \%$ and in calculations it is given by introducing the coefficient of combination of working motions whose value is: for bridge cranes $-0,8$, for mobile jibs -0.7 .

Having examined the existing technology, Arduino hardware and software base was selected. The software part consists of a free software program (IDE) for writing software and hardware firmware. The hardware part is a set of finished PCBs, manufactured by both the official manufacturer and third parties.

The fully open architecture of the system makes it easy to copy and complement the line of Arduino products. Arduino can be used both to create stand- alone objects and to connect to external control devices.

For the management of analogue crane systems, you only need to use an Arduino (Uno, Mega, or other) card, several relays that lock analogue control circuits. Also need a control device, which can be either keys, sliders or even a joystick, and even a computer or a mobile phone are needed.

To provide remote control, you need to connect Arduino to the Internet using a private network and the web-interface will probably be able to manage it from almost anywhere in the world.

Also, this hardware base gives an opportunity to install sensors of different types, which will be able to monitor the parameters and location of the cargo. After that, it will be possible to organize the output of various types of information on the monitor or control panel (fig. 2).

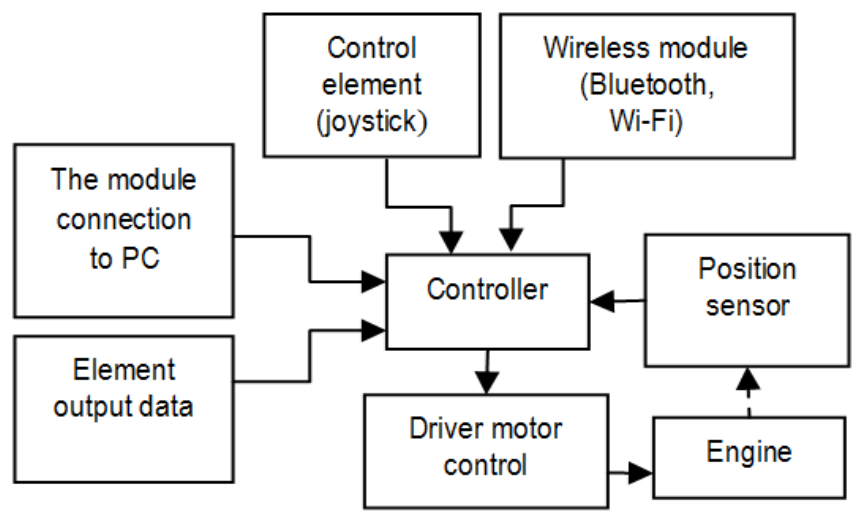

Fig. 2. Interconnection of components of an automated crane control system

Management will be carried out by such an algorithm. The control board (Arduino) tracks the position of the joystick, generates a signal that triggers the relay and activates the relay, which in turn will start the engine to perform one or another operation. However, such a method will not give you precision in control and everything will depend on the operator. Therefore it is necessary to use a method that would give an opportunity to track location. For example, to install sensors that will mark exactly where the carriage.

Such sensors can be created with the help of different technologies, for example, it is possible to establish a special line along the entire distance of motion and an optical sensor that would count on it. It is also possible to set a ruler on the engine axis that would track the engine, which in turn could also allow you to track the location by calculating the number of revolutions per unit distance. Thus, it is possible to arrange automatic motion, by programming the movement at the desired distances, which will be listed by the algorithm in the desired number of engine revolutions.

Crane management can be done either from the operator's cab, directly controlled by the controller, or remotely, by transmitting signals over wired (Ethernet) or wireless (Bluetooth, Wi-Fi) networks.
Safety in the production will increase significantly with this technology, as it will be possible to implement protection against overload, excess speed, rocking, and so on. Also, if a beacon is installed in an employee's helmet, this will allow to track the position of employees and based on these data, it will be possible to safely move the goods from one point to another without endangering people.

\section{Conclusions}

As a result of studying the possibilities of increasing the productivity of the bridge crane, the following is established:

- an effective way to increase the productivity of a batch operation lift and carry machine is to reduce the duration of the working cycle due to the combination of separate movements of the load;

- it is impossible to achieve a significant combination of separate movements only at the expense of the operator's qualification;

- the optimal combination of working movements and the choice of the optimal trajectory of cargo movement is possible due to the application;

The most advantageous option of control systems automation for crane mechanisms in today's conditions is the use of hardware and software base Arduino. 


\section{REFERENCES}

1. Aleksandrov, M.P. (1979), Podemno-transportnyie mashinyi [Load-Lifting machinery], Vyissh. shkola, Moscow, 558 p.

1. Demichev, G.M. (1991), Skladskoe i tarnoe hozyaystvo [Storage facilities and container resources], Vyissh. shk., Moscow, $192 \mathrm{p}$.

2. Vaynson, A.A. (1989), Podemno-transportnyie mashinyi [Load-Lifting machinery], Mashinostroenie, Moscow, 586 p.

3. Best Container Terminal Design in Action [online], Available at: https://youtu.be/2t2cqiQ10BE.

4. E3 Berth automation technologies for ports [online], Available at: https://youtu.be/NWsUCDyKQdQ.

5. Automatic Stacking Cranes [online], Available at: https://youtu.be/watch?v=8E0-EUdtDF8.

6. Oborudovanie dlya avtomatizirovannoy kladki kirpichnyih sten [online] Available at: https://youtu.be/tojKajx3oBE.

7. Building a House with Using Bricks Latest Technology Construction. [online] Available at: https://youtu.be/watch?v=qNUmCtCV_so.

Рецензент: д-р техн. наук, проф. П. С. Пустовойтов, Полтавський національний технічний університет імені Юрія Кондратюка, Полтава Received (Надійшла) 26.03.2018 Accepted for publication (Прийнята до друку) 30.05.2018

\section{Повышение производительности мостового крана за счет применения в его системы управления аппаратно-программных базы Arduino}

\section{В. Г. Смоляр, И. И. Слюсарь, И. А. Черницкая, В. В. Книш, А. В.Орисенко}

В статье приведены результаты исследований возможности повышения производительности мостового крана за счет внедрения в его системы управления аппаратно-программной базы Arduino. Проанализированы показатели технической производительности подъемно-транспортных машин периодического действия и проведено сокращение продолжительности рабочего цикла. Рассмотрены несколько случаев (последовательное выполнение - каждый последующий движение начинается только после завершения предыдущего; частичное совмещение - совмещаются лишь несколько отдельных движений; полное совмещение - все движения, которые кран может оказывать грузу совмещены во времени). В данной статье по результатам проведенного анализа построены управления грузоподъемной машиной за счет внедрения телекоммуникационных систем и технологий. Такими технологиями могут быть - применение микроконтроллерных средств с реализацией управления с применением проводной (Ethernet) или беспроводной (Bluetooth, Wi-Fi) сети. Потому что существует необходимость повышения производительности подъемно-транспортных машин, улучшение условий труда обслуживающего персонала, повышение надежности и долговечности элементов машины возникает необходимость создания новых, более совершенных систем управления машинами и частичной или полной автоматизации их работы. В результатах статьи было показано, что безопасность на производстве значительно увеличится с помощью данной технологии, ведь возможно будет реализовать защиту от перегрузки, превышения скорости перемещения, раскачивания, перемещения груза в зоны, где находятся люди и прочее, а управление краном возможно реализовать как из кабины оператора, управляя непосредственно контроллером, так и дистанционно передавая сигналы по проводной (Ethernet) или беспроводной (Bluetooth, Wi-Fi) сети.

Ключевые слова: мостовой кран, автоматизация, контроллер, техническая производительность, совмещение рабочих операций, Arduino, Ethernet, Bluetooth, Wi-Fi, подъемно-транспортное машина, грузоподъемная машина.

\section{Підвищення продуктивності мостового крана за рахунок застосування в його системах керування апаратно-програмної бази Arduino}

\section{В. Г. Смоляр, І. І. Слюсарь, І. О. Черницька, В. В. Книш, О. В. Орисенко}

У статті наведено результати досліджень можливості підвищення продуктивності мостового крана за рахунок впровадження в його системи керування апаратно-програмної бази Arduino. Проаналізовано показники технічної продуктивності підйомно-транспортних машин періодичної дії та проведено скорочення тривалості робочого циклу. Розглянуто декілька випадків (послідовне виконання - кожний наступний рух починається лише після завершення попереднього; часткове суміщення - суміщаються лише декілька окремих рухів; повне суміщення - всі рухи, які кран може надавати вантажеві суміщені в часі). У даній статті за результатами проведеного аналізу побудовано керування вантажопідйомною машиною за рахунок впровадження телекомунікаційних систем та технологій. Такими технологіями можуть бути - застосування мікроконтролерних засобів з реалізацією управління із застосуванням дротової (Ethernet) чи бездротової (Bluetooth, Wi-Fi) мережі. Тому що існує необхідність підвищення продуктивності підйомно-транспортних машин, покращення умов праці обслуговуючого персоналу, підвищення надійності та довговічності елементів машини виникає потреба створення нових, більш досконалих систем керування машинами та часткової чи повної автоматизації їх роботи. У результатах статті було показано, що безпека на виробництві значно збільшиться за допомогою даної технології, адже можливо буде реалізувати захист від перевантаження, перевищення швидкості переміщення, розгойдування, переміщення вантажу в зони, де перебувають люди та інше, а керування краном можливо реалізувати як 3 кабіни оператора, керуючи безпосередньо контролером, так і дистанційно передаючи сигнали по дротовій (Ethernet) чи бездротовій (Bluetooth, Wi-Fi) мережі.

Ключов і слов а: мостовий кран, автоматизація, контролер, технічна продуктивність, суміщення робочих операцій, Arduino, Ethernet, Bluetooth, Wi-Fi, підйомно-транспортна машина, вантажопідйомна машина. 